\title{
THE IMPACT OF FOREIGN TRADE IN AGRICULTURAL PRODUCTS OF BOSNIA AND HERZEGOVINA WITHIN THE FRAMEWORK OF CEFTA 2006
}

\author{
Ferhat Ćejvanović, ${ }^{1}$ Marko Ivanković, ${ }^{2}$ Marija Lasić, ${ }^{3}$ Željko Vaško ${ }^{4}$
}

\begin{abstract}
Summary
In modern conditions, characterized by the growing importance of foreign trade between the countries, relations of a country with international environment play an increasingly important role in economic development. Over the last decade the process of economic integration through the removal of barriers for the free movement of goods, services, money and people has improved job creation and economic growth. From economic cooperation with foreign countries should expect positive effects on the economy of the state if the external economic factor used in accordance with the plans and programs of economic development of a country. Thereto, there are social forces that can decide relatively independently to all elements of internal development and cooperation with foreign countries. The objective of this study was to investigate the effect of the CEFTA 2006 on the foreign trade of agricultural products in Bosnia and Herzegovina. In this respect it may be noted that foreign trade of agricultural products has an impact on the agricultural sector in Bosnia and Herzegovina.
\end{abstract}

Key words: CEFTA 2006, foreign trade, agricultural products, Bosnia and Herzegovina.

JEL: $Q 02, Q 13, Q 17$

1 Ferhat Ćejvanović, Ph.D., Associate Professor, external associate University of Tuzla, Faculty of Economics, Univerzitetska Street no. 8, 75000 Tuzla, Bosnia and Herzegovina, Phone: +387 49490 170,E-mail: ferhat.cejvanovic@gmail.com

2 Marko Ivanković, Ph.D., Full Professor, University of Mostar, Faculty of Agriculture and Food Technology, Biskupa Čule Street bb, 88000 Mostar, Bosnia and Herzegovina, Phone: + 38736 337 102, E-mail: mivankovic@faz.ba

3 Marija Lasić, M.Sc., Teaching Assistant, University of Mostar, Faculty of Agriculture and Food Technology, Biskupa Čule Street bb, 88000 Mostar, Bosnia and Herzegovina, Phone: + 38736 337 102, E-mail: marija.lasic@apfmo.org

4 Željko Vaško, Ph.D., Associate Professor, University of Banja Luka, Faculty of Agriculture, 78000 Banja Luka, Bulevar vojvode Petra Bojovića 1a, Bosnia and Herzegovina, Phone: +387 51330 929, E-mail: zeljko.vasko@agrofabl.org

EP 2014 (61) 4 (975-987) 


\section{Introduction}

After almost five years of experience in trade liberalization in Southeast Europe, gained through the implementation of bilateral free trade agreements, countries in the region have been at the end of 2006 decided to enhance their economic and trade cooperation and to conclude a single free trade agreement known as CEFTA (Central European Free Trade Agreement) 2006. Bosnia and Herzegovina $(\mathrm{BaH})$ signed the agreement on modification and accession to CEFTA on December $19^{\text {th }} 2006$ in Bucharest and the agreement entered into force on November $22^{\text {nd }} 2007$.

Even before this agreement, socio-historical, geographical, cultural and other factors had effects that Bosnia and Herzegovina most of its foreign trade performed with the countries of the Danube basin (e.g. in the period 2000-02, 60-70\%), (Vaško, 2003) of which most later joined CEFTA.

The agriculture has a special place in the process of free trade given the usually limited effects in the liberalization of agricultural products. A good example is the free trade area of Central European countries from CEFTA group where the most sensitive agricultural products are classified into individual groups and in mutually accepted rules (Ćejvanović et al, 2011).

Most countries make efforts in making the above agreements to provide a balance of trade of agricultural products in a way that they have approximately the same export options as well as the partner with whom the agreement concluded. More competitive and developed countries often granted asymmetrical concessions in favor of the weaker partner and they often remain unused. Anyway, the agreements on trade liberalization create prerequisites for the promotion of mutual trade which contributes to the growth of economic activity and strengthening the role of the market (Ćejvanović, 2009).

When signing a contract on trade liberalization it is important to take care of ensuring peer conditions to domestic economies by such agreements as well as to take care not to jeopardize a vital economic and national interests (Ćejvanović et al., 2009).

Advantages or benefits which, among other things, bringing the Agreement are as follows (MOFTER a):

1. Successful regional, and within that particular economic and trade cooperation is an important prerequisite for convergence countries of the Western Balkans to the European Community;

2. The new agreement has facilitated administration of contracts i.e. simplification of contractual relations;

3. The agreement introduces new areas of which is for Bosnia and Herzegovina particularly important the harmonization of investment conditions in the region because this country is a net recipient of investment;

4. Diagonal cumulation of origin of goods is applied among all CEFTA members; and

5. Improved mechanisms for resolving disputes, facilitating the removal of technical barriers to trade etc. 
Compared with bilateral agreements CEFTA agreement (MOFTER a) is far more complex and comprehensive. Besides being concerned plurilateral agreement it introduces some new issues that previously were not covered or significantly improves the provisions that in bilateral agreements showed as insufficiently precise or effective in application.

The complexity is reflected not only in its content but also in the structure. Since the "old" CEFTA proved to be good preparation for EU membership from its signatories it was decided to form a new agreement includes modified old one and the simultaneous accession of new members.

The signatories are: Albania, Bosnia and Herzegovina, Bulgaria, Croatia, Macedonia, Republic of Moldova, Montenegro, Romania, Serbia and mission of United Nations Interim Administration in Kosovo on behalf of Kosovo in accordance to Security Council Resolution 1244 of the United Nations. Although they signed the agreement, joining the EU on January $1^{\text {st }} 2007$ Romania and Bulgaria have ceased to be members of CEFTA. The Republic of Croatia became a full member of the EU on July $1^{\text {st }} 2013$ which means automatic termination of membership in CEFTA (Ćudina and Sušić, 2013.)

\section{Materials and methods}

The paper used secondary data sources such as data from publications of the Ministry of Foreign Trade and Economic Relations (MOFTER) Bosnia and Herzegovina, published scientific and professional papers that deal with this issue. Also been used data from $\mathrm{BaH}$ Agency for Statistics and the Department of Statistics of FBaH. Based on the data collected were used scientific methods: desk research, descriptive methods, methods of analysis and synthesis, methods of induction and deduction as well as a comparative analysis method. Control sample was used statistical reports of other CEFTA countries 2006. Reference period is $2005-2011$.

\section{Results and discussion}

In December 2006 in Bucharest was signed an agreement on amendments and accession to the Central European Free Trade Agreement (CEFTA 2006).

The agreement was subject to ratification, acceptance or approval in accordance with the requirements laid down in national law. Instruments of ratification, acceptance or approval have been deposited with the depositary. The Agreement entered into force in second half of the 2007. Bilateral agreements signed until then were cancelled on the day of the new one entry into force.

In the foreign trade of agricultural products of Bosnia and Herzegovina and the members of CEFTA 2006 can be viewed and analysed the total import and export of agricultural products. 


\section{Foreign trade of agricultural products between BaH and CEFTA 2006 members}

In order to perform comparative analysis and comparison of trends in trade of agricultural products between Bosnia and Herzegovina and other CEFTA members with overall trade in agricultural products of Bosnia and Herzegovina with the world, below are presented trade data with corresponding trends in trade in agricultural products between Bosnia and Herzegovina and CEFTA 2006 and between Bosnia and Herzegovina and the world. Data from the corresponding analyses were presented for the period 2005-2011, i.e. for the period prior to the entry into force (2005 and 2006) and the entry into force (2007-2011). In Table 1 is shown the foreign trade of $\mathrm{BaH}$ and other members of CEFTA 2006 for the period 2005-2011.

Table 1. Trade of agricultural products (1-24 CT) between Bosnia and Herzegovina and CEFTA 2005-2011

\begin{tabular}{|c|c|c|c|c|c|c|c|}
\hline Year & $\begin{array}{c}\text { Import (mil. } \\
\text { KM) }\end{array}$ & $\begin{array}{c}\downarrow \uparrow \\
\text { Import } \\
(\%) \\
\end{array}$ & $\begin{array}{c}\text { Export } \\
\text { (mil KM) }\end{array}$ & $\begin{array}{c}\downarrow \uparrow \\
\text { Export } \\
(\%) \\
\end{array}$ & $\begin{array}{c}\text { Balance } \\
\text { (mil KM) }\end{array}$ & $\begin{array}{c}\downarrow \uparrow \\
\text { Balance } \\
(\%) \\
\end{array}$ & $\begin{array}{c}\text { Export-Im- } \\
\text { port Ratio } \\
(\%) \\
\end{array}$ \\
\hline 2005. & 851.36 & 1 & 154.42 & 1 & -696.93 & 1 & $18,14 \%$ \\
\hline 2006. & 891.81 & $4.75 \%$ & 178.75 & $15.75 \%$ & \begin{tabular}{l|l|}
-713.06 \\
\end{tabular} & $2.31 \%$ & $20,04 \%$ \\
\hline 2007. & $1,136.61$ & $27.45 \%$ & 229.10 & $28.17 \%$ & -907.51 & $27.27 \%$ & $20,16 \%$ \\
\hline 2008. & $1,240.00$ & $9.10 \%$ & 304.38 & $32.86 \%$ & -935.62 & $3.10 \%$ & $24,55 \%$ \\
\hline 2009. & $1,198.00$ & $-3.39 \%$ & 315.24 & $3.57 \%$ & \begin{tabular}{l|l|}
-882.76 \\
\end{tabular} & $-5.65 \%$ & $26,31 \%$ \\
\hline 2010. & $1,281.20$ & $6.94 \%$ & 361.36 & $14.63 \%$ & -919.84 & $4.20 \%$ & $28,20 \%$ \\
\hline 2011. & $1,344.14$ & \begin{tabular}{l|l|}
$4.91 \%$ \\
\end{tabular} & 446.16 & $23.47 \%$ & \begin{tabular}{l|l|}
-897.98 \\
\end{tabular} & $-2.38 \%$ & $33,19 \%$ \\
\hline
\end{tabular}

Source: Author's calculations based on data collected by the Agency for Statistics of BaH (http://www.bhas.ba/index.php?option=com_publikacija\&view=publikacija pregled\&ids $=2 \& \mathrm{id}=7 \& \mathrm{n}=$ Vanjska $\% 20$ trgovina $)$.

Note: CT - Customs tariffs, KM - Convertible Marka (BiH national currency).

Next table (Table 2) shows total world foreign trade of agricultural products $\mathrm{BaH}$.

Table 2. Trade in agricultural products (1-24CT) between Bosnia and Herzegovina and the World in the period 2005-2011

\begin{tabular}{|l|r|r|r|r|r|r|r|}
\hline Year & $\begin{array}{c}\text { Import } \\
\text { (mil. KM) }\end{array}$ & $\begin{array}{c}\downarrow \uparrow \\
\text { Import } \\
\mathbf{( \% )}\end{array}$ & $\begin{array}{c}\text { Export } \\
\text { (mil KM) }\end{array}$ & $\begin{array}{c}\downarrow \uparrow \\
\text { Export } \\
\mathbf{( \% )}\end{array}$ & $\begin{array}{c}\text { Balance } \\
\text { (mil KM) }\end{array}$ & $\begin{array}{c}\downarrow \uparrow \\
\text { Balance } \\
(\mathbf{\%})\end{array}$ & $\begin{array}{c}\text { Export- } \\
\text { Import } \\
\text { Ratio (\%) }\end{array}$ \\
\hline 2005. & $1,981.63$ & $/$ & 223.30 & $/$ & $-1,758.32$ & & $11.27 \%$ \\
\hline 2006. & $1,944.94$ & $-1.85 \%$ & 258.76 & $15.88 \%$ & $-1,686.18$ & $-4.10 \%$ & $13.30 \%$ \\
\hline 2007. & $2,238.99$ & $15.12 \%$ & 324.88 & $25.55 \%$ & $-1,914.12$ & $13.52 \%$ & $14.51 \%$ \\
\hline 2008. & $2,620.15$ & $17.02 \%$ & 410.10 & $26.23 \%$ & $-2,210.05$ & $15.46 \%$ & $15.65 \%$ \\
\hline 2009. & $2,389.03$ & $-8.82 \%$ & 452.77 & $10.40 \%$ & $-1,936.26$ & $-12.39 \%$ & $18.95 \%$ \\
\hline 2010. & $2,502.40$ & $4.75 \%$ & 553.08 & $22.16 \%$ & $-1,949.32$ & $0.67 \%$ & $22.10 \%$ \\
\hline 2011. & $2,769.95$ & $10.69 \%$ & 612.20 & $10.69 \%$ & $-2,157.74$ & $10.69 \%$ & $22.10 \%$ \\
\hline
\end{tabular}

Source: Author's calculations based on data collected by the Agency for Statistics of BaH (http://www.bhas. ba/index.php?option=com_publikacija\&view=publikacija_pregled\&ids $=2 \& i d=7 \& n=V a n j s k a \% 20 \operatorname{trg} 0 v i n a)$. 


\section{Import of agricultural products in Bosnia and Herzegovina from members of CEFTA 2006 (2005-2011)}

Import of agricultural products from CEFTA members 2006 to Bosnia and Herzegovina has been constantly increasing since 2005 until 2011 but at lower growth rates compared to the growth rates of agricultural products export from $\mathrm{BaH}$ to member countries of CEFTA 2006 for the mentioned period. The exception was in 2009 when the effects of the global economic crisis affected the decline in import of agricultural products from CEFTA 2006 in Bosnia and Herzegovina when there was a decline of 3.39\%. From Figure 1 is visible growth rate of agricultural products import in Bosnia and Herzegovina from member countries of the CEFTA 2006.

Figure 1. Annual growth rate of import of agricultural products (in \%) in Bosnia and Herzegovina from the CEFTA and the World

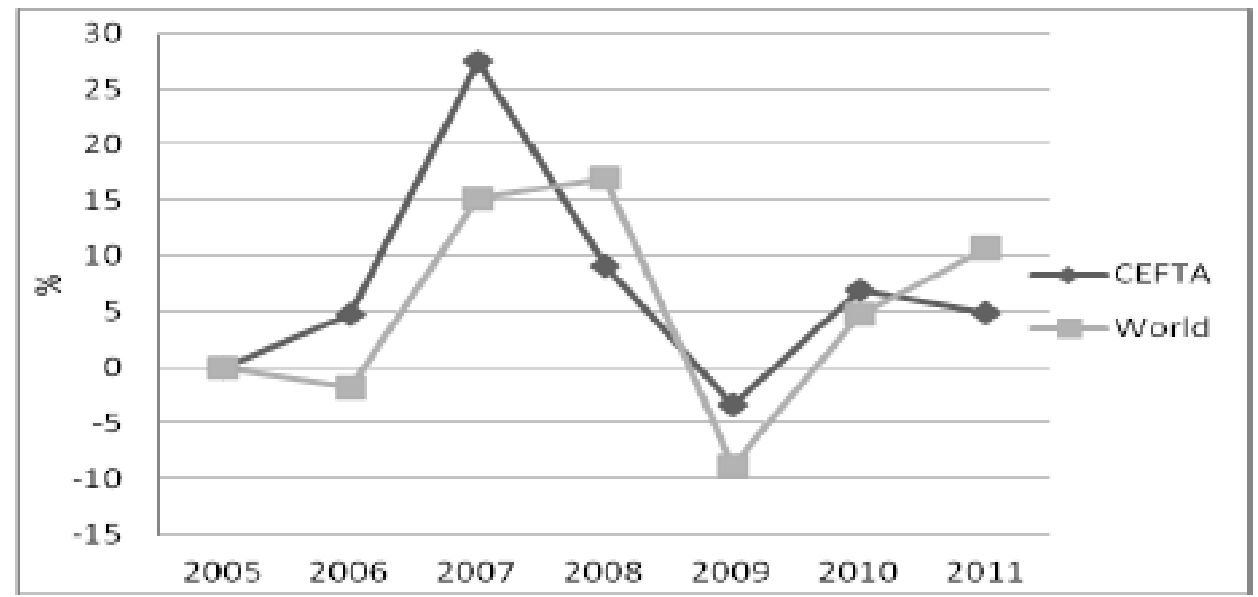

Source: Author's calculations based on data collected by the Agency for Statistics of BaH (http://www.bhas. ba/index.php?option=com_publikacija\&view=publikacija_pregled\&ids=2\&id=7\&n=Vanjska\%20trgovina).

The major increase in import of agricultural products from CEFTA 2006 was recorded in 2007, 27.45\% when the CEFTA 2006 Agreement entered into force (for BaH November $\left.22^{\text {nd }} 2007\right)$. A significant increase in import of agricultural products from the member countries of the CEFTA 2006 during 2007 affected the overall increase in import of agricultural products in $\mathrm{BaH}$ which was $15.12 \%$ for 2007 . The reason for the tight correlation between the increases in import of agricultural products from CEFTA countries with an increase in total import of agricultural products in BIH was the significant participation of CEFTA in total import of agricultural products in BIH, which in 2007 reached a peak of 51\%.

For 2008 the rate of increase of agricultural products import from the CEFTA 2006 was reduced to $9.10 \%$ while total import of agricultural products in Bosnia and Herzegovina had a growth of $17.02 \%$. The reason for the higher rate of growth of total imports of agricultural products in Bosnia and Herzegovina than the growth rate of imports from CEFTA 2006 was the entry into force of the Interim Stabilisation and Association Agreement with the EU (July $1^{\text {st }} 2008$ ) which resulted in an increase in of import of agricultural products from the 
EU at the expense of imports from CEFTA members 2006. Therefore, the participation of the member countries of the CEFTA 2006 in total imports of agricultural products in BIH in 2008 was reduced from $51 \%$ to $47 \%$.

Import of agricultural products from CEFTA members 2006 in 2009 had a decline of 3.39\%, as already mentioned, due to the impact of the global economic crisis. Also, the total import of agricultural products in Bosnia and Herzegovina in this year had decline of $8.82 \%$.

In 2010 import of agricultural products from CEFTA members 2006 grew at a rate of $6.94 \%$, while total import of agricultural products this year had a slightly lower rate of 4.75\%. In 2011 the situation was reversed and the total import of agricultural products in the Bosnia and Herzegovina had a higher growth rate $(10.69 \%)$ than the rate of growth of agricultural imports from CEFTA members 2006 (4.91\%). The participation of the member countries of the CEFTA 2006 in total import of agricultural products in Bosnia and Herzegovina in the period 2005 to 2011 ranged from 42\% in 2005 to $51 \%$ in 2007 and 2011.

\section{Export of agricultural products from Bosnia and Herzegovina to CEFTA 2006 (2005-2011)}

Export of agricultural products from Bosnia and Herzegovina to 2006 CEFTA member countries is constantly growing in the reference period from 2005 to 2011. This growth was not interrupted nor in 2009 when the effects of the global economic crisis affected the decline in import of agricultural products from CEFTA members 2006 and the World. In Figure 2 is shown growth in export of agricultural products (in \%) from BIH to CEFTA 2006 and the World.

Figure 2. Annual growth rates of export of agricultural products (in \%) from BIH to CEFTA and the World

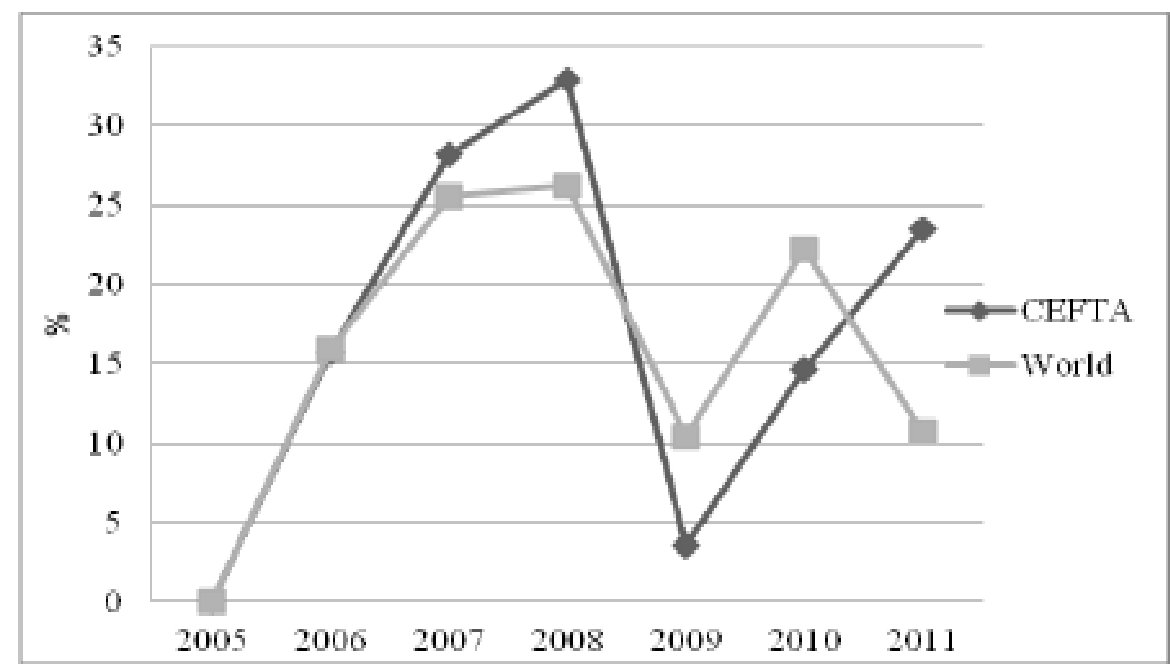

Source: Author's calculations based on data collected by the Agency for Statistics of BaH (http://www.bhas. ba/index.php?option=com_publikacija\&view=publikacija_pregled\&ids=2\&id=7\&n=Vanjska\%20trgovina). 
As for import a significant increase in export of agricultural products in member countries OF CEFTA 2006 was recorded in 2007 by $28.17 \%$. Significant growth of export of agricultural products in CEFTA 2006 in 2007 affected the overall growth of export of agricultural products from $\mathrm{BaH}$ which in 2007 grew by $25.55 \%$. A significant effect of increasing export of agricultural products in CEFTA 2006 to increase in total export of agricultural products is the result of a dominant share of the member countries of the CEFTA 2006 in total agricultural exports of Bosnia and Herzegovina which in 2007 accounted for $71 \%$. Despite the entry into force of the Interim Agreement on Stabilization and Association Agreement (July 1st 2008) the largest increase of export of agricultural products in CEFTA 2006 was recorded in 2008, while total export of agricultural products from $\mathrm{BaH}$ had an increase of $26.23 \%$.

The participation of the member countries of the CEFTA 2006 in total agricultural exports of Bosnia and Herzegovina in 2008 had its maximum of 74\%. In 2009, despite the economic downturn, continued to increase of export of agricultural products from $\mathrm{BaH}$ in CEFTA 2006, but at a much lower growth rate of only $3.57 \%$, while the total export of agricultural products from BIH grew at a slightly higher rate of $10,40 \%$. In 2010, export of agricultural products in CEFTA 2006 continues to grow at a rate of $14.63 \%$, while the total export of agricultural products this year again had a slightly higher growth rate of $22.16 \%$.

In 2011 the situation was reversed and the rate of growth of export of agricultural products to other countries CEFTA 2006 was $10.69 \%$, but much higher rate of export $(23.47 \%)$ was recorded in trade with the world. Participation of CEFTA 2006 members in the total export of agricultural products from $\mathrm{BaH}$ in the period 2005 to 2011 ranged from $65 \%$ in 2010 to $74 \%$ in the 2008 .

\section{Agricultural products trade deficit between Bosnia and Herzegovina and CEFTA 2006 (2005-2011)}

Bosnia and Herzegovina in the period 2005-2011 achieved a negative foreign trade balance or deficit in trade of agricultural products between BaH and CEFTA 2006, but also in the entire $\mathrm{BaH}$ agricultural products trade with the World. Bosnia and Herzegovina is a net importer of agricultural products.

In Figure 3 is apparent motion of the growth rate of foreign trade deficit in agricultural trade between $\mathrm{BaH}$ and CEFTA 2006 and trade between $\mathrm{BaH}$ and the World. 
Figure 3. Annual growth rates of the deficit in the trade of agricultural products between BaH-CEFTA and BaH-World (in \%)

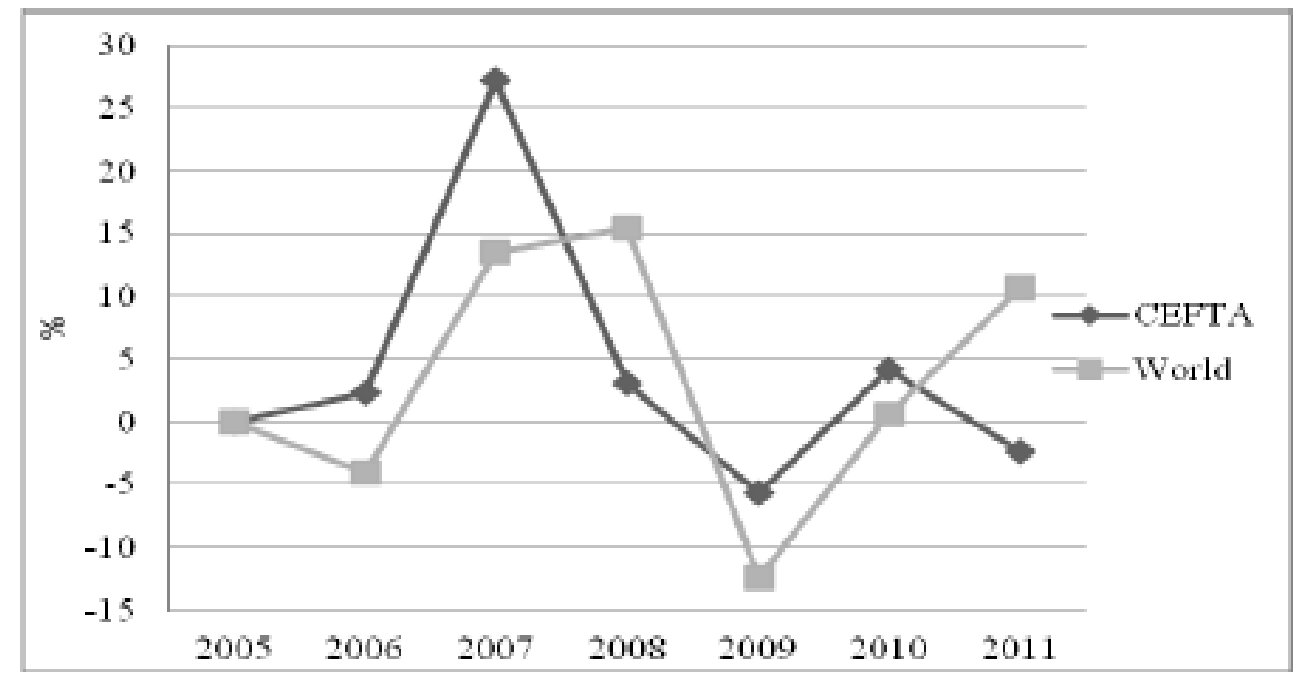

Source: Author's calculations based on data collected by the Agency for Statistics of BaH (http://www.bhas. ba/index.php?option=com_publikacija\&view=publikacija_pregled\&ids=2\&id=7\&n=Vanjska\%20trgovina).

Trends in agricultural products foreign trade deficit with CEFTA members 2006 and the world have the same direction but different intensities. The only exception is when it comes to directions of movement deficits in 2011when the deficit with members of CEFTA 2006 had a slight decrease of $2.38 \%$ while at the same time the total deficit trade in agricultural products grew by $10.69 \%$.

As Figure 3 shows the largest growth in the deficit in agricultural trade with CEFTA members 2006 was recorded in 2007 (27.27\%) when the CEFTA 2006 Agreement entered into force, while in 2008 when the Interim Agreement on Stabilization and Association Agreement entry into force there was an increase in the deficit in trade in agricultural products $\mathrm{BaH}$ more than the deficit in trade in agricultural products within CEFTA 2006.

Due to the significantly higher value of import of agricultural products the CEFTA 2006 and the World in relation to the value of export of the same (which shows low coverage of import by export) growth rates and decline of trade deficit in agricultural products BIH are mostly directly related to the movement of agricultural import in $\mathrm{BIH}$, while the impact of export of agricultural products from BIH to the movement of deficits significantly lower. In Table 3 is shown the share of CEFTA 2006 foreign trade with BaH agricultural products. 
Table 3. Share of CEFTA 2006 in trade with BaH agricultural products

\begin{tabular}{|c|c|c|c|}
\hline Year & $\begin{array}{c}\text { Share in total Import } \\
(\mathbf{\%})\end{array}$ & $\begin{array}{c}\text { Share in total Export } \\
\mathbf{( \% )}\end{array}$ & $\begin{array}{c}\text { Share in total Deficit } \\
\mathbf{( \% )}\end{array}$ \\
\hline 2005 & $43 \%$ & $69 \%$ & $40 \%$ \\
\hline 2006 & $46 \%$ & $69 \%$ & $42 \%$ \\
\hline 2007 & $51 \%$ & $71 \%$ & $47 \%$ \\
\hline 2008 & $47 \%$ & $74 \%$ & $42 \%$ \\
\hline 2009 & $50 \%$ & $70 \%$ & $46 \%$ \\
\hline 2010 & $51 \%$ & $65 \%$ & $47 \%$ \\
\hline 2011 & $49 \%$ & $73 \%$ & $42 \%$ \\
\hline
\end{tabular}

Source: Agency for Statistics of Bosnia and Herzegovina, (edited by authors), (www.bhas.ba/index. php?option=com_publikacija\&view=publikacija_pregled\&ids=2\&id=7\&n=Vanjska\%20trgovina).

The export-import ratio of agricultural products in BaH trade with CEFTA 2006 in the period from 2005 to 2011 ranged from $18.14 \%$ in 2005 to $33.19 \%$ in 2011 There is an evident trend of improving the coverage of import by export in that period. Compared to the export-import ratio of total foreign trade BIH agricultural products, export-import ratio within CEFTA 2006 is much more favourable. Export-import ratio of the total foreign trade of BIH agricultural products in the period 2005 - 2011 ranged from $11.27 \%$ (2005) to $22.10 \%$ (2010 and 2011).

\section{Consequences of Croatian accession to the $\mathbf{E U}$}

Bosnia and Herzegovina and Republic of Croatia (RC) have traditionally good trade and economic relations. The Republic of Croatia was the first country that Bosnia and Herzegovina has signed a bilateral agreement on trade liberalization. Naturally after signing the agreement CEFTA trade relations between the two countries are governed by this agreement. Trade Balance (RC-B\&H) was on the Croatian side. But for many of $\mathrm{BaH}$ agricultural and food products the Republic of Croatia has become a major export market (Ćejvanović and Džafić, 2011). 
Figure 4. Foreign trades in agricultural products between Bosnia and Herzegovina and Republic of Croatia

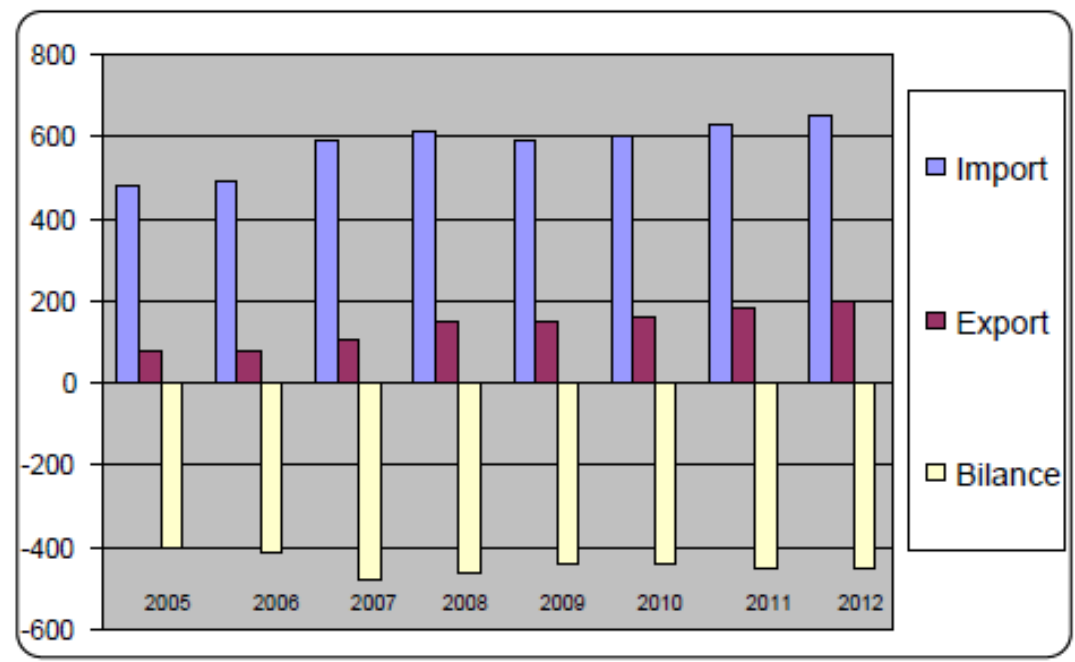

Source: Agency for Statistics of Bosnia and Herzegovina (http://www.bhas.ba/index. php?option=com_publikacija\&view=publikacija_pregled\&ids=2\&id=7\&n=Vanjska\%20trgovina).

Balance in trade with the Croatia as in the case of balance with other CEFTA countries increased from year to year, of course, for reasons which we have already passed. That's the lowest coverage of import by export was in 2005 while in the other direction was greatest turn in 2012.

Table 4. The coverage of import by export in agricultural products trade between Bosnia and Herzegovina and the Croatia

\begin{tabular}{|c|c|c|c|c|c|c|c|c|}
\hline Year & $\mathbf{2 0 0 5}$. & $\mathbf{2 0 0 6 .}$ & $\mathbf{2 0 0 7 .}$ & $\mathbf{2 0 0 8}$. & $\mathbf{2 0 0 9}$. & $\mathbf{2 0 1 0 .}$ & $\mathbf{2 0 1 1 .}$ & $\mathbf{2 0 1 2 .}$ \\
\hline Coverage (\%) & 18,93 & 19,74 & 20,69 & 25,10 & 25,82 & 28,68 & 30,73 & 31,13 \\
\hline
\end{tabular}

Source: Agency for Statistics of Bosnia and Herzegovina (http://www.bhas.ba/index. php?option=com_publikacija\&view=publikacija_pregled\&ids $=2 \& i d=7 \& n=V a n j s k a \% 20 \operatorname{trg}$ ovina).

Republic of Croatia on July $1^{\text {st }} 2013$ became a full member of the European Union, which closes one chapter of trade cooperation and opens up completely new. As already mentioned trade links between Republic of Croatia and Bosnia and Herzegovina have so far been regulated by CEFTA agreement, however after EU membership this agreement is automatically suspended. Suspending the agreement CEFTA with Republic of Croatia Bosnia and Herzegovina is likely to lose the most important export market for agricultural products worth an average of 150.87 million. It is very difficult for BIH to compensate this loss of market. In such a situation agricultural enterprises will be forced to reduce production or purchase from the family farm and it would be a major blow for domestic agricultural production which will feel the consequences already in the 2014. 
Table 5. Export of agricultural products from BaH to Croatia

\begin{tabular}{|l|c|c|c|c|c|l|l|l|}
\hline Year & 2005 & 2006 & 2007 & 2008 & 2009 & 2010 & 2011 & 2012 \\
\hline Export (mil. KM) & 86,51 & 91,45 & 125,05 & 157,58 & 156,35 & 175,24 & 201,22 & 213,53 \\
\hline
\end{tabular}

Source: Agency for Statistics of Bosnia and Herzegovina (http://www.bhas.ba/index. php?option=com_publikacija\&view=publikacija_pregled\&ids=2\&id=7\&n=Vanjska\%20trgovina).

From agricultural products represented in the structure of export largely participate producers of animal products especially milk and milk products so that the greatest effects can be expected in this sector. In addition to producers of milk and dairy products, we can expect consequences for sectors of the meat (whether it be on unprocessed meat or processed meat) and of plant products in potato sector. All listed products in addition to being the largest volume of exports to Croatia are "critical" because they are still (working conditions of export) cannot be exported to the EU market. Given counted it means $\mathrm{BIH}$ can export to Croatia only products that can be exported to the EU market. In BIH such products is only few, especially when it comes to animal products and their processed products.

The table shows that the export from BIH to Croatia ranged from 86.5 up to 213.5 million, which represents the largest export of agricultural products in one country that makes Croatia's major trading partner in agricultural products. With Croatian membership in the EU this export for most of (and most important) products will effectively be stopped because they missed the chance for an agreement before accession Croatia to the EU.

The second and perhaps more important issue is the problem of transit through Croatia and the EU about which are still performed trilateral negotiations between BIH, Croatia and the EU. Since Croatia became a member of the EU it is valid for EU legislation on the movement and transit of animals and products of plant origin. This can represent a serious problem for local exporters because alternative transportation and alternative export routes make export more expensive and therefore it below probably reduced after. The aforementioned problems, although agronomic professions indicated to, are not adequately resolved for political reasons from political positions holders and the tremendous consequences will be felt by BIH agriculture (Bilić et al., 2011).

\section{Conclusion}

Member countries of the CEFTA 2006 are the most important trade partner of Bosnia and Herzegovina when it comes to agricultural trade (MOFTER b). So, it is a most important export market for agricultural products from Bosnia and Herzegovina, as evidenced by the participation of the member countries of the CEFTA 2006 in total agricultural exports from Bosnia and Herzegovina in the period 2005-2011 by as much as $74 \%$ in 2008 and $73 \%$ in 2011 .

CEFTA 2006 is the only export market of Bosnia and Herzegovina for products of animal origin in 2011: meat, milk and dairy products, and meat products. Export of agricultural products from Bosnia and Herzegovina in CEFTA 2006 in the period 2005-2011 is constantly growing 
with very high growth rates, for example, $32.86 \%$ in 2008 . This growth was interrupted in 2009 when the effects of the global economic crisis reflected in the decline in total imports agricultural products in Bosnia and Herzegovina. The constant growth of export agricultural products from Bosnia and Herzegovina in CEFTA 2006 had a positive impact on improving the coverage of import by export agricultural products from the CEFTA member states 2006, from $18.14 \%$ in 2005 to a record $33.19 \%$ in 2011 . The export-import ratio is greater than the total coverage of import by export agricultural products of Bosnia and Herzegovina with the world, which is in 2011 amounted to $22.10 \%$.

On the other hand, CEFTA 2006 is the most important importer of agricultural products in Bosnia and Herzegovina with its share in total imports from 42\% in 2005 to $51 \%$ in 2007 and 2011. Import of agricultural products from the of CEFTA 2006 in Bosnia and Herzegovina has been constantly increasing since 2005 to 2011 but with much lower growth rates compared to the rates of growth of export of agricultural products from BIH in CEFTA 2006 in the mentioned period. The exception is in 2009 when the effects of the global economic crisis affected the decline in import of agricultural products from CEFTA 2006 in BIH.

Bosnia and Herzegovina in the period 2005 - 2011 realized a negative foreign trade balance or deficit in agricultural trade between Bosnia and Herzegovina and CEFTA, and in total trade in agricultural products of Bosnia and Herzegovina with the world. The reason for this is the fact that Bosnia and Herzegovina is a net importer of agricultural products and its production cannot meet their own needs. Trends in deficit agricultural products in BIH trade with CEFTA countries and the world have the same direction, but with different intensities. The total deficit in trade in agricultural products in 2011 grew at a rate of $10.69 \%$, while the deficit with members of CEFTA 2006 has a decrease of $2.38 \%$.

Based on the foregoing, we can conclude that the signing of the CEFTA had a positive effect on the growth of export agricultural products from Bosnia and Herzegovina in CEFTA (Ćejvanović and Džafić, 2012) in the reference period 2005-2011 which contributed to the coverage of import by export agricultural products within CEFTA 2006 in the period from 2005 to 2011 almost doubled.

\section{Literature}

1. Agency for Statistics ofBosnia andHerzegovina,Publications, Economic statistics(Foreign trade), accessedat15.10.2013.,availableat:http://www.bhas.ba/index.php?option=com publikacija\&view=publikacija pregled\&ids=2\&id=7\&n=Vanjska $\% 20$ trgovina

2. Bilić, B., Ivanković, M., Matić, M., Rupčić, M. (2011): Sustainable model of fruit growing in BIH on three selected crops within the CEFTA market, Economics of Agriculture, Vol. LVIII, SI-1, str. 34-40.

3. Ćejvanović, F. (2009): Uticaj CEFTA na vanjskotrgovinsku razmjenu u Bosni i Hercegovini, zbornik radova, Međunarodni naučni skup Tuzla, Ekonomski fakultet Univerziteta u Tuzli, str. 140-144. 
4. Ćejvanović, F., Džafić, Z. (2011): Sporazum CEFTA-2006 i učinci vanjskotrgovinske razmjene - slučaj Bosne i Hercegovine, Znanstveni skup - Trgovina kao pokretač razvoja srednje i jugoistočne Europe, zbornik radova Ekonomskog fakulteta Sveučilišta u Zagrebu, str. 129-141.

5. Ćejvanović, F., Džafić, Z. (2012): Vanjskotrgovinska razmjena poljoprivrednih proizvoda u okvirima CEFTA 2006 i utjecaj na održivi ruralni razvoj Bosne i Hercegovine, Znanstveni skup - Perspektive trgovine 2012 - Trgovina u kontekstu održivog razvoja, Zbornik međunarodnog znanstvenog skupa Zagreb, str. 129-141.

6. Ćejvanović, F., Hodžić, K., Terzić, L. (2009): Utjecaj CEFTA na vanjskotrgovinsku razmjenu poljoprivrednih proizvoda u Bosni i Hercegovini, Tranzicija, Vol. 11, No. 23-24, pp. 10-19.

7. Ćudina, A., Sušić, G. (2013): Utjecaj pristupanja hrvatske europskoj uniji na trgovinske i gospodarske odnose sa zemljama CEFTA-e, Ekonomski pregled, vol. 64(4), str. 376396.

8. Ministry of Foreign Trade and Economic Relations of Bosnia and Herzegovina (MOFTER a), (2007): Komentar na odredbe Sporazuma o izmjeni i pristupanju centralnoevropskom sporazumu o slobodnoj trgovini (CEFTA 2006), Sarajevo, December 2007, available at: http://www.mvteo.gov.ba/CEFTA/dokumenti bos linkovi pdf/Komentari\%20na $\% 20$ odredbe $\% 20$ CEFTA $\% 202006 \% 20$ Sporazumabos.pdf

9. Ministry of Foreign Trade and Economic Relations of Bosnia and Herzegovina (MOFTER b), available documentation related to CEFTA Agreement, accessed at: 17.09. 2014., available at: www.mvteo.gov.ba/CEFTA/dokumenti/default. aspx?id=5119\&langTag=bs-BA

10. Vaško, Ž. (2003): Spoljnotrgovinska razmjena Bosne i Hercegovine sa zemljama Podunuvalja, zbornik radova Foruma podunavskih zemalja, Banja Luka, str. 55-62. 